\title{
岡山県下のクリニック・診療所におけるリウマチ診療・ 病診連携の実態に関する研究
}

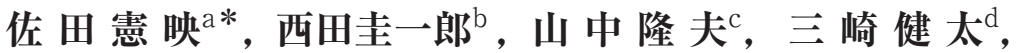 \\ 若林 宏 ${ }^{\mathrm{a}}$, 篠田潤子 ${ }^{\mathrm{e}}$, 高木 徹, 矢野隆介 ${ }^{\mathrm{g}}$, \\ 中村明彦 ${ }^{\mathrm{h}}$ ，難波良文 ${ }^{\mathrm{i}}$, 守田吉孝 ${ }^{\mathrm{j}}$, 小山芳伸 ${ }^{\mathrm{k}}$, \\ 山本惠嗣 ${ }^{1}$, 江澤和 彦 ${ }^{\mathrm{m}}$, 太田裕介 ${ }^{\mathrm{n}}$, 吉原由樹 ${ }^{\circ}$, \\ 三好信 也 $^{\circ}$, 霜田将光 ${ }^{\mathrm{m}}$, 兒井正明 ${ }^{\mathrm{p}}$, 吉永泰颜 ${ }^{\mathrm{a}}$, \\ 林 充 ${ }^{\mathrm{r}}$, 山村昌弘 ${ }^{\mathrm{s}}$, 橋詰博 彳亍 $^{\mathrm{t}}$
}

岡山大学大学院医歯薬学総合研究科 a腎・免疫・内分泌代謝内科学, b人体構成学, ${ }^{\mathrm{P}}$ 南岡山医療センター リウマチ科, d 倉敷中央病院 内分泌代謝・リウマチ内科, e岡山労災病院 整形外科, f䍏山赤十字病院 整形外科, k膠原病リウマチ内科, $\mathrm{g}$ 矢野内科医院，hおさふねクリニック，川崎医科大学附属病院 i整形外科，jリウマチ・膠原病科，1山本整形外科医院， m倉敷スイートホスピタル 内科, n香川労災病院 整形外科, 倉敷成人病センター o 整形外科, qリウマチ膠原病内科,

$\mathrm{p}$ 岡山市民病院 整形外科，r佐用中央病院 整形外科， $\mathrm{s}$ 岡山済生会総合病院 内科，笠岡第一病院 整形外科

\section{Hospital and clinic cooperation for the treatment of rheumatoid arthritis in Okayama Prefecture, Japan}

\author{
Ken-ei Sada ${ }^{\text {a* }}$, Keiichiro Nishida ${ }^{\mathrm{b}}$, Takao Yamanaka ${ }^{\mathrm{c}}$, Kenta Misaki ${ }^{\mathrm{d}}$, \\ Hiroshi Wakabayashi ${ }^{\mathrm{a}}$, Junko Shinoda ${ }^{\mathrm{e}}$, Toru Takagi ${ }^{\mathrm{f}}$, Ryusuke Yano ${ }^{g}$, \\ Akihiko Nakamura $^{\mathrm{h}}$, Yoshifumi Nanba ${ }^{\mathrm{i}}$, Yoshitaka Morita ${ }^{\mathrm{j}}$, Yoshinobu Koyama ${ }^{\mathrm{k}}$, \\ Keiji Yamamoto ${ }^{1}$, Kazuhiko Ezawa ${ }^{\mathrm{m}}$, Yusuke Ota ${ }^{\mathrm{n}}$, Yoshiki Yoshihara ${ }^{\circ}$, \\ Shinya Miyoshi ${ }^{\circ}$, Masamitsu Natsumeda ${ }^{\mathrm{m}}$, Masaaki Usui ${ }^{\mathrm{p}}$, Yasuhiko Yoshinaga ${ }^{\mathrm{q}}$, \\ Takashi Hayashi $^{\mathrm{r}}$, Masahiro Yamamura ${ }^{\mathrm{s}}$, Hiroyuki Hashizume ${ }^{\mathrm{t}}$
}

Departments of a Medicine and Clinical Science, ${ }^{b} H u m a n$ Morphology, Okayama University Graduate School of Medicine, Dentistry and Pharmaceutical Sciences, Okayama 700-8558, Japan, 'Department of Rheumatology, Incorporated Administrative Agency, Minami-Okayama Medical Center, Okayama 701-0304, Japan, dDepartment of Endocrinology, Metabolism and Rheumatology,

Kurashiki Central Hospital, Okayama 710-0052, Japan, e'Department of Orthopedic Surgery, Okayama Rosai Hospital,

Okayama 702-8055, Japan, Departments of fOrthopedic Surgery, kRheumatology, Okayama Red Cross General Hospital, Okayama 700-0941, Japan, 'sYano Clinic, Okayama 703-8205, Japan, hOsafune Clinic, Okayama 701-4264, Japan, Departments of ${ }^{\mathrm{i}}$ Orthopedic Surgery, ${ }^{\mathrm{j} R h e u m a t o l o g y, ~ K a w a s a k i ~ M e d i c a l ~ S c h o o l, ~ O k a y a m a ~ 701-0114, ~ J a p a n, ~}$

'Yamamoto Orthopedic Clinic, Okayama 710-0142, Japan, mDepartment of Medicine, Kurashiki Sweet Hospital, Okayama 710-0016, Japan, nDepartment of Orthopedic Surgery, Kagawa Rosai Hospital, Kagawa 763-0013, Japan,

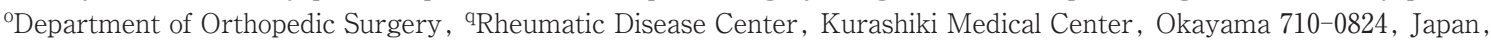
${ }^{p}$ Department of Orthopaedic Surgery, Okayama City Hospital, Okayama 700-0833, Japan, rDepartment of Orthopedic Surgery, Sayo Central Hospital, Hyougo 679-5301, Japan, sCenter for Rheumatology, Okayama Saiseikai General Hospital, Okayama 700-0013, Japan, tDepartment of Orthopedic Surgery, Kasaoka Daiichi Hospital, Okayama 714-0043, Japan

Objective: To survey the current status and problems of cooperation between clinics and hospitals in Okayama Prefecture, Japan for the treatment of rheumatoid arthritis (RA).

Methods: We distributed a questionnaire to 300 of the 983 Okayama Prefecture clinics that had either an internal medicine or orthopedic surgery department, from December 2013 to February 2014. The questionnaire covered practice pattern for RA treatment in clinics, current status of the hospital and clinic cooperation, and acceptance of the biologic therapy .

Results: One hundred clinics responded to the questionnaire. Seventy percent of the clinics reported making referrals to rheumatologists before the initiation of RA treatment, and half of the other $30 \%$ of the clinics administered

\footnotetext{
平成26年 9 月 4 日受理

* $7700-8558$ 岡山市北区鹿田町 $2-5-1$

電話：086-235-7235 FAX : 086-222-5214

E-mail : sadakenn@md.okayama-u.ac.jp
} 
methotrexate as the first-line treatment for RA by their own decision. Sixty-six clinics cooperated with flagship hospitals, conducting medical and laboratory examinations, providing prescriptions, and treating common diseases of patients. These clinics expected the cooperating rheumatologists to follow-up patients every 3 to 6 months and to make the diagnosis, make decisions regarding RA treatment changes, and perform surgery. Seventy-one percent of the clinics responded that cooperation with a hospital is possible even for patients who are administered biologics. As reasons for no cooperation with the flagship hospitals, clinics noted the lack of information about rheumatologists in the area and recent trends in the management of RA.

Conclusion: The current study reported, for the first time, the actual conditions of management of RA in clinics, as well as future problems of hospital and clinic cooperation in Okayama Prefecture.

キーワード：病診連携（hospital and clinic cooperation）, 関節リウマチ (rheumatoid arthritis), 生物学的製剂（biologics）, メトトレキサート（methotrexate）

\section{緒言}

関節リウマチ (RA) は自己免疫の機序を介して関節を中 心とした滑膜に炎症を起こし関節破壊・変形を来す疾患で ある、RA 患者では治療が十分に行われなければ関節破壊 に伴い生活の質 (QOL) ${ }^{1)}$ や日常生活動作 (ADL) の低下 を来すだけでなく生命予後にまで影響することが知られて いる2).

RA 診療はメトトレキサート (MTX) および生物学的製 剂の登場により劇的に変化し, 寛解を目指すことが可能な 疾患となった ${ }^{3)}$. 治療が飛躍的に進歩した一方で治療の特 殊性が増したため, これまで一般内科や一般整形外科のみ で治療を受けてきた RA 患者がRA 䛦療を専門とする医師 のもとで加療を受ける頻度は増加していると思われる。

昨今の RA 診療では, 早期診断・早期治療がガイドライ ンでも推奨されており ${ }^{4)}$, 特に診療所・クリニックから基 幹病院へ紹介のタイミングは治療開始より診断の段階が多 くなっていることが予測されるがその実態は明らかでな い.また, 病診連携も含めてその後の診療がどういった形 で行われているかも不明である。

適切な治療により疾患活動性のコントロールが可能とな れば，基幹病院への頻回の通院は必ずしも必要ではなく, 診療所・クリニックとの病診連携が可能である。通院の利 便性など患者のメリットだけでなく, 診療所・基幹病院の 本来の機能維持のために病診連携は不可欠であり今後もさ らに推進する必要があるが病診連携の現状やその問題点な ども明らかとされていない。

我々は岡山県下のリウマチ治療の均露化を図る目的で 2010年から, 基幹病院の専門医が中心となり OKAYAMA リウマチネットワークを組織し, 年 2 回の研究会を主催し て活動を行ってきた。現在までのところ, ネットワーク所 属施設は基幹病院と一部のクリニックに留まっており, 診 療所・クリニックとのネットワークづくりが十分に行えて いない.この度, 診療所・クリニックにおける RA 診療の
実態の把握，病診連携の実態・問題点を明らかにするため に本研究を行った。

\section{対象と方法}

\section{1. 研究デザイン}

本研究では自記式調査票を用いて匿名調査を行った。

\section{2 . 対象}

岡山県下で内科・整形外科を標榜する診療所・クリニッ クを対象とした。

\section{3 . 方 法}

\section{1 ) 対象施設の抽出}

まず岡山県下で内科・整形外科を標榜している全施設り ストを用いて, 二次医療圈ごとの全 5 地点（県南東部保健 医療圈, 県南西部保健医療圈, 高梁保健医療圈, 真庭保健 医療圈，津山・英田保健医療圈）に分類し層化した。想定 する母集団は約 1,000 施設で, 母集団で想定する RA 診療実 施施設を $20 \%$ と想定し最大許容誤差を $5 \%$ ，信頼度を $95 \%$ とした時のサンプルサイズは197と算出された.調査票の回 答率を $66 \%$ と推定し最終的に依頼対象施設を 300 施設とし た. 各層からのサンプリング数は比例割り当てとし, 各層 での総施設数に比例して無作為に依頼対象施設300施設を 抽出した。

\section{2 ）調查の依頼}

依頼対象となった 300 施設に 2013 年 12 月に封書にて調査 協力を依頼した。返信がない施設については 1 回のみ再度 協力を依頼する連絡を行った。2014年 1 月に返信用はがき にて調査協力の承諾が得られた施設に調査票を送付した。

\section{3 ）調查票の回収}

匿名で記入された調査票は郵送にて回収した。返信がな い施設については2014年 2 月に 1 回のみ再度提出を依頼す る連絡を行った。

\section{$4 ）$ 調查票の保管}

回収した調査票は完全に匿名化した状態で保管した。 


\section{5 ）倫理的事項}

本研究は, 観察研究であり文部科学省, 厚生労働省によ って作成された「疫学研究の倫理指針」に従って実施した。 調査は匿名の調查票を用いて行い, 謝礼は支払わなかった。 本研究は「疫学研究」に当たり, 岡山大学倫理委員会の承 認を得て行っている(承認番号：疫学766).

\section{4. 調查項目}

調查票では以下の調查項目についての調査を行った.

\section{1 ）施設・医師特性}

施設所在, 臨床経験年数, RA 診療年数, 取得専門医, 診療分野.

\section{2 ) RA 診療の穾態}

RA 診療の有無, 行われている診療（診断, 治療, 紹介 のタイミング).

\section{3 ）病診連携の実態}

病診連携の有無, 病診連携での役割, 基幹病院に希望す る診療内容, 連携の問題点 (自由記述).

\section{4 ）生物学的製剂の使用について}

情報提供の方法, 処方実態, 基幹病院からの逆紹介の受 け入れ。

\section{5 . 解析方法}

得られたデー夕を基に施設特性，医師特性，RA 診療の 実態，病診連携の実態，生物学的製剤の使用，のそれぞれ の項目について集計・記述した。

病診連携の有無と RA 診療実態についてカイ二乗検定を 用いて比較検討した.

\section{結果}

\section{1 . 施設・回答者特性}

対象となる 983 施設は高梁・新見圈 47 施設, 真庭圈 27 施 設, 津山・英田圈109施設, 県南西部圈287施設, 県南東部 圈513施設に分類層化された. 各医療圈からそれぞれ高梁・ 新見圈14施設 $(5 \%)$, 真庭圏 8 施設 $(3 \%)$, 津山・英田 圈33施設 $(11 \%)$, 県南西部圈88施設 $(29 \%)$, 県南東部圈 157施設（52\%）の計300施設に調査協力を依頼した。

依頼した 300 施設のうち，1 回の再依頼の結果150施設 （50\%）から協力可能との回答が得られ, 最終的に2014年 2 月までに 100 施設 $(33 \%)$ から回答を得た.

回答者の所属施設は高梁・新見圈 2 施設 $(2 \%)$, 真庭圈 3 施設 ( $3 \%)$, 津山・英田圈 8 施設 $(8 \%)$, 県南西部圈 31 施設 $(31 \%)$, 県南東部圈56施設 $(56 \%)$ であり母集団と 同様の分布を示した．回答者特性を表 1 に示す．回答者の 臨床経験年数は平均 30 年であり，80\%が内科医師，17\%が 整形外科医師であった。日本りウマチ学会専門医は $1 \%$, 日本整形外科学会認定リウマチ医は $5 \%$ であり, すべて所
表 1 回答者特性 $(\mathrm{N}=100)$

\begin{tabular}{|c|c|}
\hline 所属施設特性 & \\
\hline 病床 (有床：無床) & $15: 85$ \\
\hline 緊急検査可能 & $46 \%$ \\
\hline 超音波あり & $82 \%$ \\
\hline CTあり & $13 \%$ \\
\hline MRI あり & $4 \%$ \\
\hline \multicolumn{2}{|l|}{ 診療分野 } \\
\hline 内科 & $80 \%$ \\
\hline 整形外科 & $17 \%$ \\
\hline 外科 & $13 \%$ \\
\hline 臨床経験年数（年 $+/$-標準偏差 $)$ & $30+/-9$ \\
\hline 臨床経験年数（内科） & $30+/-9$ \\
\hline 臨床経験年数（整形外科） & $31+/-11$ \\
\hline 臨床経験年数（外科） & $29+/-9$ \\
\hline 日本リウマチ学会認定教育施設での勤務歴あり & $20 \%$ \\
\hline \multicolumn{2}{|l|}{ 取得専門医 } \\
\hline 日本リウマチ学会認定専門医 & $1 \%$ \\
\hline 日本整形外科学会認定専門医 & $13 \%$ \\
\hline 日本整形外科学会認定りウマチ医 & $5 \%$ \\
\hline 日本リウマチ財団登録医 & $4 \%$ \\
\hline 日本内科学会認定医 & $43 \%$ \\
\hline 特になし & $28 \%$ \\
\hline
\end{tabular}

在は県南部であった。

\section{2. 関節リウマチ診療の実態}

RA 診療に関する調查では,「主体的に行っている」と回 答したのは $18 \%$ ，「連携の依頼があったときのみ行ってい る」と回答したのは $65 \%$ であり，何らかの形で RA に関わ っている医師が83\%を占めた。

RA が疑われる患者が受診した際の対応では,「検査を行

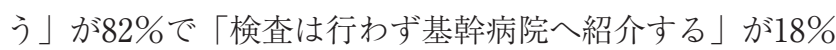
であった、「検査を行う」と回答した医師 82 名のうち検査内 容の記載があった81名が診断の際に参考にしている検査を 図 1 に示す.リウマチ因子や抗 CCP 抗体などの免疫学的検 査や CRP ・血沈など炎症を評価する検査など血液検査が 多くの施設で行われ，次いでレントゲン検査が行われてい た、ヨーロッパリウマチ学会・アメリカリウマチ学会の診 断基準など近年発表された診断基準も22\%の医師で活用さ れていた。

RA と診断または RA を疑った際には，検査を行った 82 


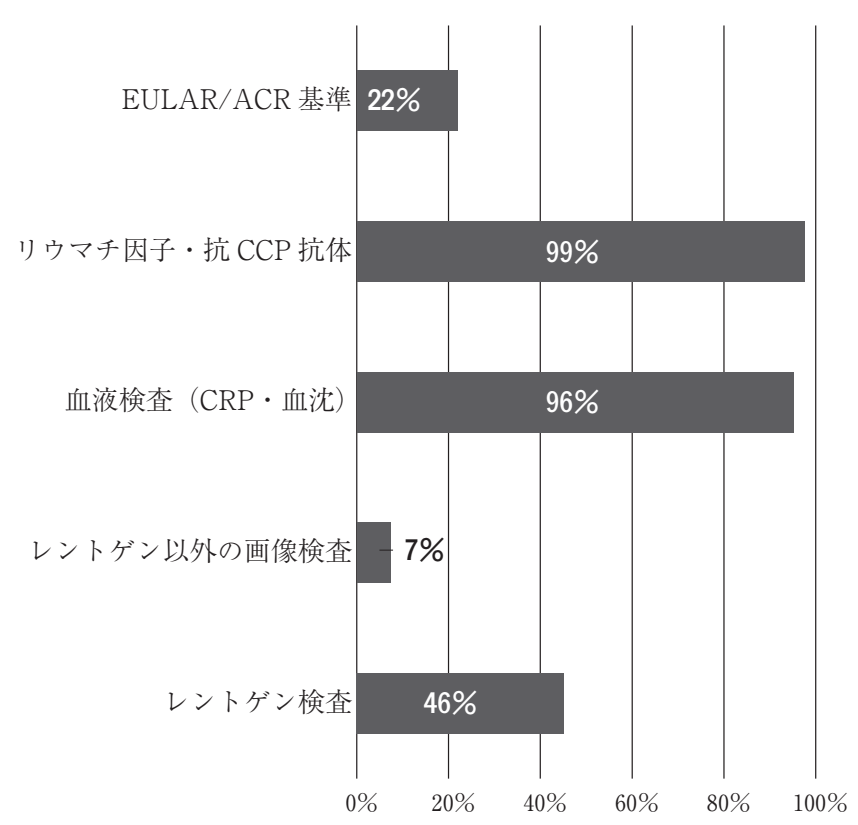

図 1 関節リウマチの診断の際に参考にされる検査項目等 関節リウマチが疑われる患者が受診した際に「検査を行う」と 回答した医師82名のうち検査内容の記載があった81名の回答. EULAR：ヨーロッパリウマチ学会, ACR：アメリカリウマチ 学会「レントゲン以外の画像検査」については特に内容を定義 せず質問した。

名の医師のうち 54 名（66\%）が「基幹病院へ紹介する」と 回答した。このうち内科医では78\%が基幹病院へ紹介する と回答したのに対し整形外科医では14\%と診療科間で統計 学的な有意差を認めた $(\mathrm{P}<0.0002)$. (禁忌等がなければ) メトトレキサート (MTX) で加療すると回答した医師が 12 名 (15\%), MTX 以外の疾患修飾抗リウマチ薬 (DMARDs) で治療を開始すると回答した医師が13名（16\%）であった。 治療を開始すると回答した医師25名のその後の治療抵抗 例に対する方針を図 2 に示す.MTX, MTX 以外の DMARDs で治療効果が得られない場合には20名 (80\%)の医師が「基 幹病院へ紹介する」と回答しており, その後生物学的製剤 を開始する，手術が必要となった段階で紹介すると回答し た医師は少数であった。

基幹病院へ紹介するタイミングのまとめを図 3 に示した。

\section{3 ．病診連携に関する実態}

$\lceil\mathrm{RA}$ 診療に関する病診連携を行っている」と回答した 医師は66名 (66\%) であった。病診連携を行う際, 診療所・ クリニックが担っている役割について得られた回答を図 4 に示す. 過半数の施設で担っている役割として, 診察・評 価 $(46$ 名 $(70 \%))$, 検査・評価 $(39$ 名 $(59 \%))$, 生物学的 製剂を除く処方 $(38$ 名 $(58 \%))$, common diseaseへの対 応 $(35$ 名 $(53 \%))$ などが挙げられた。

一方で図 5 に示す基幹病院に期待する役割では,「診断や

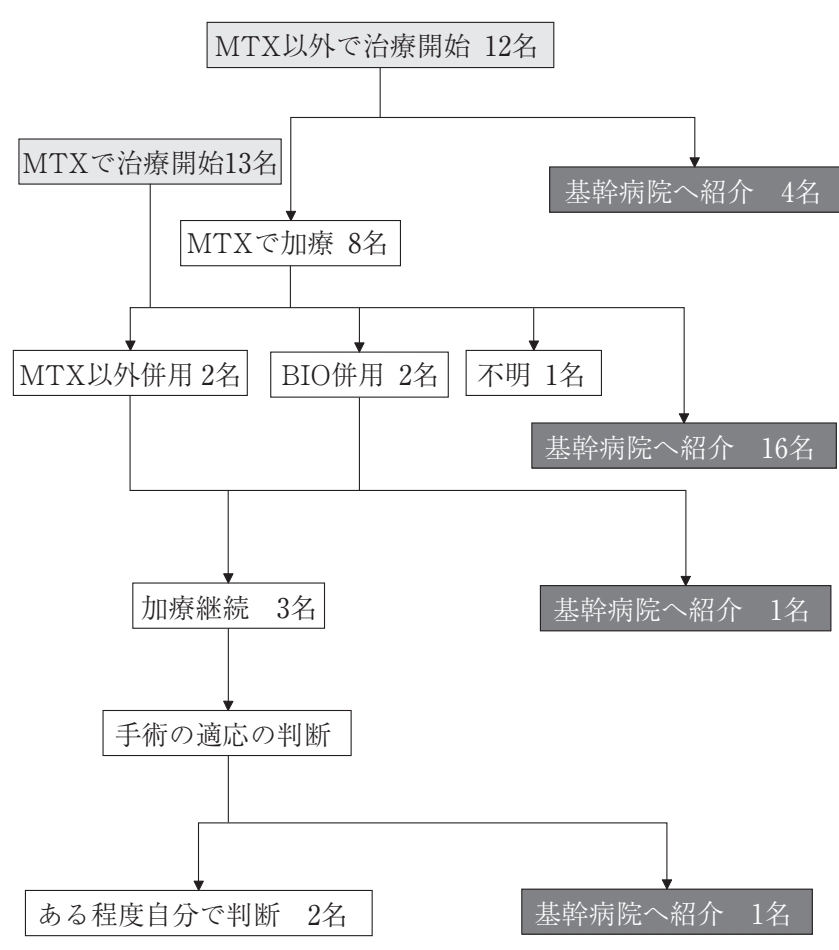

MTX：メトトレキサート, BIO：生物学的製剤

困 2 治療開始してからの対応

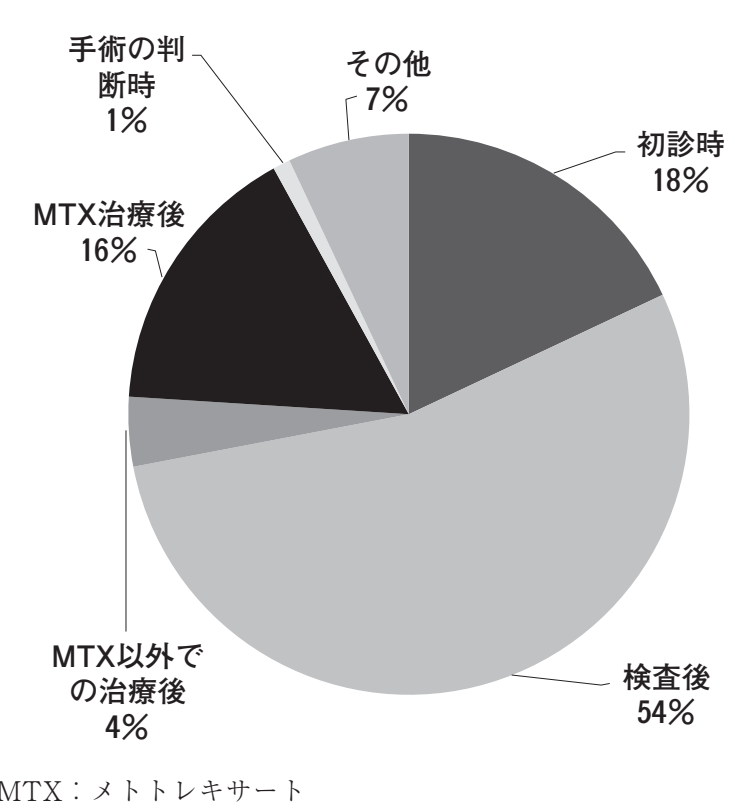

図 3 基幹病院へ紹介するタイミング

治療方針の決定」，「合併症・副作用への対応」が過半数を 占めていた。また「画像検査」や「手術」なども $40 \%$ を超 えている一方で,「処方」や「血液・尿検査」については $30 \%$ 未満に留まった。適切な連携の頻度としては「 $3 \sim 6$ カ月」 とした医師が約 $80 \%$ 占めていた。 


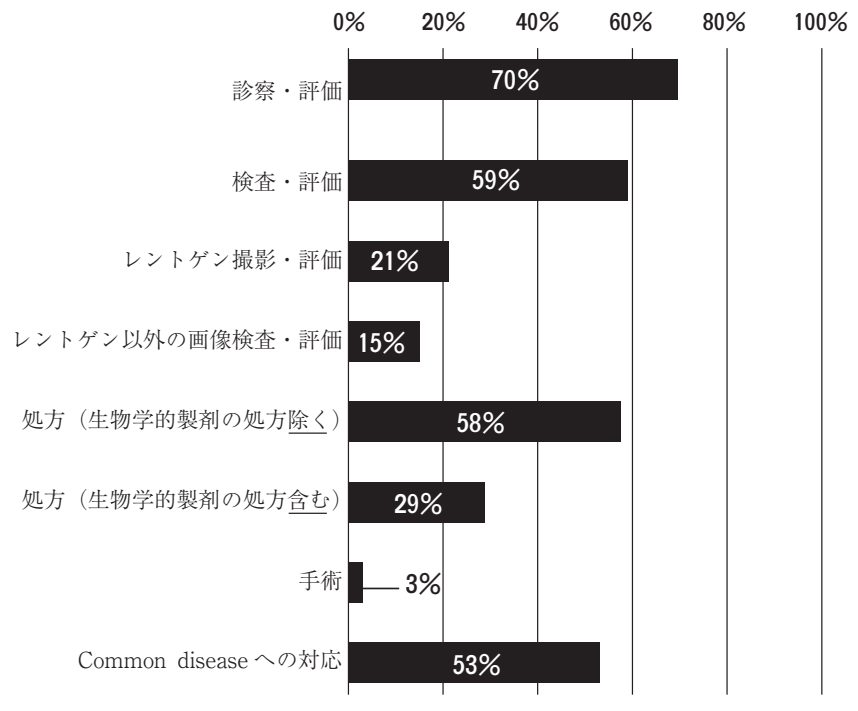

病䛦連携を行っている医師 66 名の回答

図 4 クリニック・診療で担っている役割
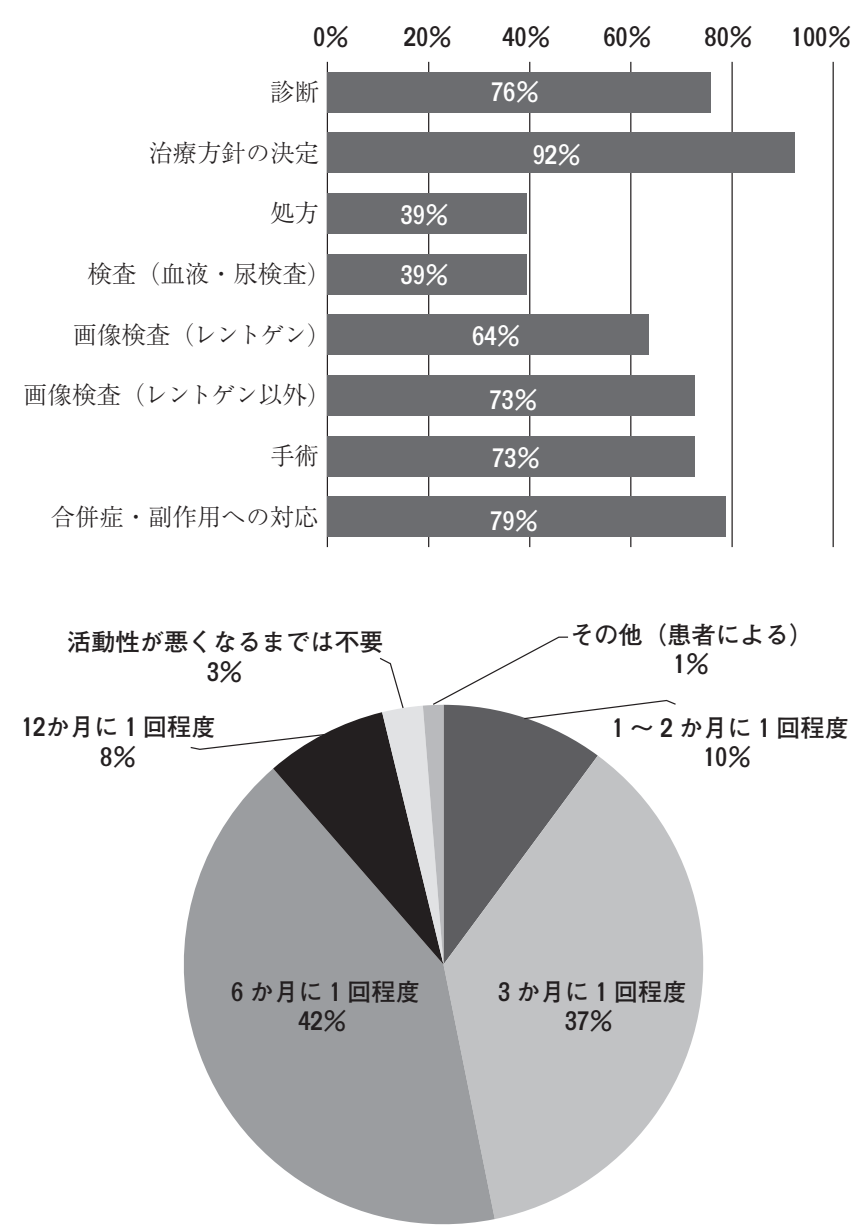

図 5 病診連携を行っている66施設の医師が考える, 基幹病院 に期待する役割と適切なフォロー頻度
RA を疑う患者が受診した時の対応として，病診連携を 行っていない施設では行っている施設と比較して有意に 「検査は行わず基幹病院へ紹介する」の割合が高かった (29\% vs 12\%，P = 0.03). しかし「検査を行う」と回答 した医師においては病診連携の有無で参考にする項目の違 いは見られなかった。

病診連携を行っていない理由を表 2 に示す.「どこと連携 していいのか分からない」「使っている薬剤の使用経験がな いため処方ができない」などの回答が多くみられた。

\section{4. 生物学的製剂使用時の病診連携（図 6 ）}

実際に生物学的製剤の処方を行っている施設は $20 \%$ に留 まる一方で，処方する機会がないと答えた施設も40\%程度 存在した。また生物学的製剤を使用している患者の逆紹介 については「可能」または「条件により可能」とした施設 が71\%であった。

\section{考察}

岡山県下での RA 診療における病診連携の調査を行っ た。診療所・クリニックにおける専門医は日本リウマチ学 会認定専門医が $1 \%$ ，日本整形外科学会認定リウマチ医が $5 \%$ \%で，診療所・クリニックのみで専門医が介入した 治療を受けることが困難な実情が明らかとなった。

診療所・クリニックに専門医が少なく，近年の RA 治療

表 2 病診連携を行っていない理由 病診連携を行っていない医師 34 名（複数回答）

\begin{tabular}{|c|c|}
\hline どこと連携していいのか分からない & 12 \\
\hline 使っている薬剤の使用経験がないため処方ができない & 12 \\
\hline $\begin{array}{l}\text { 活動性の悪化や合併症の発生時などにどう対応したら } \\
\text { いいか分からない }\end{array}$ & 7 \\
\hline 患者を紹介しても逆紹介がない & 5 \\
\hline 検査結果の評価ができない & 4 \\
\hline 他の診療が多忙のため患者の受け入れができない & 4 \\
\hline 経営的なメリットがない & 0 \\
\hline 病診連携を行っていたが連携先の対応に不満があった & 0 \\
\hline $\begin{array}{l}\text { その他 } \\
\text { ・患者が専門医での治療を希望していると思われる. } \\
\text { ・患者の希望を優先. よって, 病院には集中しない. } \\
\text { (MTX, 生物学的製剤を使う患者は返してもらって } \\
\text { いません.) } \\
\text { ・院内処方の為薬剤に限りがある. 検査が外注の為. } \\
\text { ・その時その時で紹介する. } \\
\text { ・紹介があれば診させていただいていますが（特に高 } \\
\text { 齢の方は）病診連携というほとは診ていません. } \\
\text { ・依頼がない. } \\
\text { ・機会が無い. }\end{array}$ & \\
\hline
\end{tabular}



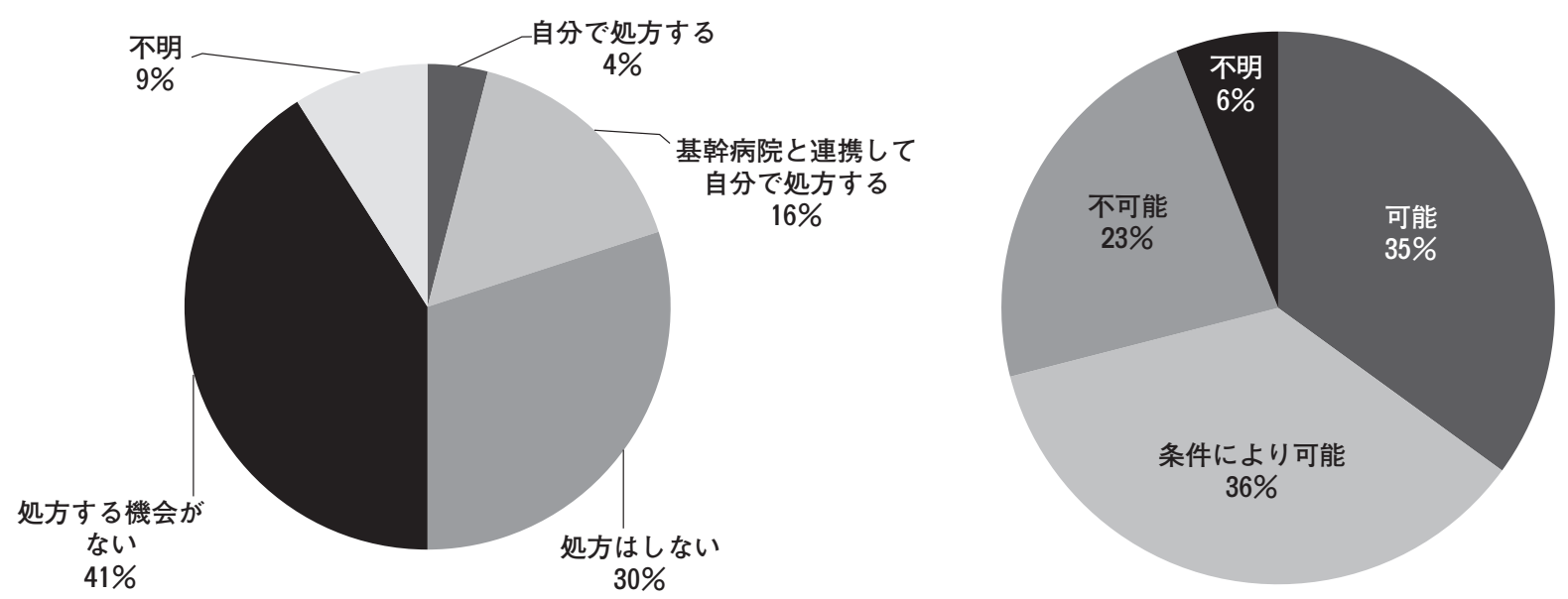

図 6 生物学的製剤の処方と逆紹介の受け入れ

が大きく変貌していることもあり，72\%の施設では初回治 療を開始する前に基幹病院への紹介が行われていた。一方 で, 診療所・クリニックで治療開始される 28 施設のうち 12 施設（全体の $12 \%$ ）では禁忌でない限りは RA 治療の第一 選択として推奨されているMTXで治療を開始されてい た。基幹病院では適切な治療が行われる（72\%）及び診療 所・クリニックに扔ける MTX での治療開始が適切な治療 である（12\%）と仮定すれば，岡山県下で関節リウマチと 診断された患者の $84 \%$ がガイドラインで推奨されている適 切な治療を開始されていることになる4).

病診連携は66\%の施設で行われており, それらの施設で は主に「診察」,「検査」,「処方」,「common diseaseへの 対応」などの役割を担っていた。治療前に基幹病院へ紹介 を行う施設が74\%であることを考えると, 治療開始後は基 幹病院または診療所単独で診療を行われている患者が存在 することが推察される。一方で34名の医師が病診連携を行 っていないと回答していた。中には「基幹病院での継続的 な加療が必要な場合」や「患者が連携を希望しない」など のケースもあるとは思われる。病診連携を行わない理由と しては,「どこと連携していいのか分からない」「使ってい る薬剤の使用経験がないため処方ができない」の理由が多 かった。我々が行っている「顔の見える」病診連携の会へ の積極的参加の呼びかけや周知, 最新の医療情報に関する 講演会などを通じた知識の共有, 質疑応答を介した疑問点 の解消などにより, 病診連携システムや RA 治療に関する 情報提供をさらに充実させることで病診連携を行うことが 可能なクリニック・診療所を増加させることが可能かもし れない.

また病診連携を行っているクリニック・診療所からは特 に $3 \sim 6$ カ月に 1 回の定期的なフォローアップを基幹病院 に求める声が多く，またその役割として，「治療方針の決
定」や「画像診断」・手術」などが求められていた。フォ ローアップや副作用発現時の対応を確実に行えるシステム を個々のクリニック・診療所で具体化することで病診連携 の質をさらに向上させることが可能かもしれない.

生物学的製剂を処方している施設は20\%であった。これ までに信州リウマチネットワークで行われた調査では2007 年度の生物学的製剂使用率が $35.1 \%$ と報告されているが, 対象となっている医師が基幹病院に所属する医師なども含 まれるため一般診療での現状を反映しているとは言い難い5).

生物学的製剂を投与中の患者の逆紹介に関する調査では $23 \%$ が受け入れ不可と回答していた. 逆に $71 \%$ の施設が「可 能」・「条件により可能」と回答しており，処方の実態調查 でも「処方する機会がない」と回答した施設が40\%を超え ていたことから，生物学的製剤を処方する患者において病 診連携が可能な施設を拡大していく余地は残されていると 思われる，長野県の87施設の皮膚科専門医に対する2012年 の乾癬診療の実態調査に扔いて, 適応となる患者がいても 生物学的製剤の処方を行っているクリニックはなかったと 報告されている．診療科の違いが大きいと思われるが今回 の検討から岡山県下に扔ける生物学的製剂投与患者受け入 れの積極的な姿勢がうかがえる6).ただし，クリニック・ 診療所での薬剤の準備などは経営にも関わる問題であり, 様々な種類の生物学的製剂が登場している現在の状況下で は, 地域単位での連携など新たな連携システムの構築が必 要かもしれない. また生物学的製剤の投与方法も連携可否 の重要な要因となる可能性がある。

本研究の限界として, 回答者がRA 診療に関心の高い集 団となっていること，つまり“回答者バイアス”の影響は 考慮する必要がある，従って本研究では RA 診療・病診連 携の実態が高く評価され，母集団全体の実態より過大評価 されている可能性がある。また回答率が $33 \%$ と低く, 十分 
に母集団を代表した結果であるとはいえない。

また本研究では ADL や疾患活動性など病診連携におい て考慮すべき患者側の要因は含まれておらず，また専門医 の偏在や通院困難者など病診連携を行いたくても行えない 状況については考慮されていないため, 病診連携の必要性 の判断，通院が行えない患者での連携方法などについても 今後考慮する必要がある。現在岡山県下では情報共有シス テム「晴れやかネット」などが展開されている，RA 診療 においても検査結果の共有や無駄な検査の回避など, 円滑 な病診連携の一助となるであろう。

本研究はわが国で初の一般診療を行っている診療所・ク

リニックでの RA 診療実態を, 疫学的手法を用いて明らか にした報告である。本研究成果をもとに，リウマチネット ワークでの病診連携をさらに発展させていく必要がある。 今後リウマチネットワークに所属いただけるクリニッ ク・診療所が増えればネットワークへの所属の有無での比 較によりリウマチネットワークの活動の意義の評価も可能 となる。

\section{結 論}

岡山県下での RA 診療においては，84\%で適切な診療が 開始されていることが推察された。今後さらに病診連携を 発展させるためには，適切な情報提供やより質の高い連携 体制を構築する必要がある。

\section{謝辞}

調査の依頼, 調查票の回収に多大なるご尽力をいただきました岡山 大学大学院医歯薬学総合研究科腎. 免疫 - 内分泌代謝内科学事務員 の和泉亜希子さん，丸山智美さんに深謝いたします。

またお忙しいところ調査への参加可否, 調査票の記入にご協力いた だきました先生方に厚く御礼申し上げます.

\section{利益相反}

OKAYAMA リウマチネットワークでこれまで開催した研究会の 共催は次の通りです。アステラス製薬株式会社，アッヴィ合同会社， エーザイ株式会社，小野薬品工業株式会社，参天製薬株式会社，武田 薬品工業株式会社, 田辺三菱製薬株式会社, 中外製薬株式会社, ファ イザー株式会社, ブリストル・マイヤーズ株式会社, ヤンセンファー マ株式会社，ユーシービージャパン株式会社.

\section{文献}

1) Kosinski M, Kujawski SC, Martin R, Wanke LA, Buatti MC, Ware JE Jr, Perfetto EM : Health-related quality of life in early rheumatoid arthritis : impact of disease and treatment response. AJMC (2002) 8, 231-240.

2) Scire CA, Lunt M, Marshall T, Symmons DP, Verstappen $\mathrm{SM}$ : Early remission is associated with improved survival in patients with inflammatory polyarthritis: results from the Norfolk Arthritis Register. Ann Rheum Dis (2014) 73, 16771682.

3 ) Aga AB, Lie E, Uhlig T, Olsen IC, Wierod A, Kalstad S, Rodevand E, Mikkelsen K, Kvien TK, Haavardsholm EA : Time trends in disease activity, response and remission rates in rheumatoid arthritis during the past decade : results from the NOR-DMARD study 2000-2010. Ann Rheum Dis (2013) . doi : 10.1136/annrheumdis-2013-204020.

4 ) Smolen JS, Landewe R, Breedveld FC, Buch M, Burmester G, Dougados M, Emery P, Gaujoux-Viala C, Gossec L, Nam J, Ramiro S, Winthrop K, et al. : EULAR recommendations for the management of rheumatoid arthritis with synthetic and biological disease-modifying antirheumatic drugs : 2013 update. Ann Rheum Dis (2014) 73, 492-509.

5 ）山崎 秀, 鈴木明夫，金物壽久，浦野房三，鈴木貞博，松田正 之, 加藤博之：関節リウマチの生物学的製剂治療における医療連 携上の問題点. 中部リウマチ（2010）40，86-87.

6 ）小林 彩, 吉川美香, 小川英作, 奥山隆平：長野県における乾痒 治療の現状と病診連携の可能性．西日本皮膚科（2013）75，346349. 